\title{
The January 2006 low ozone event over the UK
}

\author{
M. Keil, D. R. Jackson, and M. C. Hort \\ Met Office, FitzRoy Road, Exeter, EX1 3PB, UK \\ Received: 7 July 2006 - Published in Atmos. Chem. Phys. Discuss.: 5 September 2006 \\ Revised: 18 December 2006 - Accepted: 19 February 2007 - Published: 22 February 2007
}

\begin{abstract}
In this paper we present a case study of a record low ozone event observed over the UK in January 2006. We focus on the dynamical processes that cause this event. This is done by examining the observations, meteorological analyses and back trajectories calculated by the NAME III atmospheric dispersion model. We show that this model, hitherto only used for tropospheric pollution studies, can be an important and effective tool for the examination of transport in the upper troposphere/lower stratosphere (UTLS) and midstratosphere regions.

A record low total ozone column of $177 \mathrm{DU}$ was observed at Reading, UK, on 19 January 2006. Low ozone values were also recorded at other stations in Northwest Europe around this date. Ozonesonde measurements indicate the depletion is occurring in two distinct vertical regions, with around a third of the reduction in total ozone column values originating from the mid-stratosphere and the rest from the UTLS region. Evidence suggests that air inside the stratospheric polar vortex was poor in ozone prior to 19 January and the occurrence of a major stratospheric warming shifted this air over Northwest Europe. In addition we show that moderate ozone depletion, related to the lifting of the tropopause and divergence in the lower stratosphere associated with the presence of an anticyclone, is also a plausible mechanism for the record low ozone column that is observed.
\end{abstract}

In order to confirm that both mid-stratosphere and UTLS transport processes are responsible for the record low ozone values, we perform turbulent back trajectory calculations using the Met Office NAME III model. The results show that air parcels in the mid-stratosphere that arrive over the British Isles on 19 January originate in the polar vortex, and furthermore that air parcels near the tropopause arrive from low latitudes and are transported anticyclonically. Therefore this strongly suggests that the record low ozone values are due to a combination of a raised tropopause with increased divergence in the lower stratosphere and the presence of low ozone stratospheric air aloft.

Correspondence to: M. Keil

(mike.keil@metoffice.gov.uk)

\section{Introduction}

In this paper we document the very low ozone event observed over the UK in January 2006, and investigate the dynamical processes that caused this event. It is not uncommon to observe reductions in the total ozone column at such latitudes in winter, since it is well-known that column total ozone levels undergo fluctuations associated with the passage of tropospheric weather systems. Cases where depletion occurs are often referred to as "ozone mini-holes" and have been documented by a number of authors e.g. Newman et al. (1988); McKenna et al. (1989); Peters et al. (1995); James (1998). Such mini-holes occur frequently in mid and high latitudes (James, 1998), but they are rarely as deep as the one that we choose to examine in this paper. Therefore, to begin with, we summarise the dynamical processes that are believed to cause moderate strength and intense mini-holes.

The ozone depletion observed in a mini-hole of moderate strength results from the presence of an anticyclone in the upper troposphere/lower stratosphere (UTLS). These anticyclones are present as a result of poleward Rossby-wave breaking events at mid latitudes. The associated raising of the tropopause means that a greater proportion of the column is occupied by ozone-poor tropospheric air. In addition, the divergence of ozone-rich air out of the column in the lower stratosphere leads to a further reduction in total ozone. This has been the subject of numerous studies. For example, James and Peters (2002) performed a Lagrangian study of mini-holes and showed the holes to be associated with anomalous warm anticyclonic flow in the upper troposphere. Koch et al. (2005) looked at potential vorticity composites of central European mini-holes. These highlighted the importance of long-range meridional transport in the formation of mini-hole, whilst local adiabatic vertical displacement of isentropes play an additional, less important role in minihole formation. Further studies, e.g. Hood and Soukharev (2005); Peters and Entzian (1999), have examined trends in total ozone in the northern hemisphere in recent decades, and have found that changes in UTLS dynamics and the BrewerDobson circulation have a strong influence on total ozone

Published by Copernicus GmbH on behalf of the European Geosciences Union. 
decadal changes and, by implication, related trends in ozone mini-hole frequency.

As already stated, mini-holes of moderate strength occur frequently in mid and high latitudes (James, 1998), but a smaller number of very intense mini holes are often observed in combination with a sudden stratospheric warming or other distortion of the stratospheric polar vortex. In these events the air within the vortex is ozone-poor, due to the very cold temperatures within the vortex and the associated chemical destruction of stratospheric ozone. The horizontal advection of this ozone-poor air over a region where the ozone column is already reduced due to the presence of a UTLS anticyclone leads to an even larger reduction in the total ozone column. Case studies of such events include Petzoldt et al. (1994); Petzoldt (1999) and Allen and Nakamura (2002). The latter reported a total ozone column of 165 DU on 30 November 1999 over Europe observed by the Total Ozone Mapping Spectrometer (TOMS). This is a record for this instrument and this location. Allen and Nakamura used a tracer transport model to reconstruct the ozone field in November 1999 and thus to determine the mechanism that caused the very low ozone column over Europe.

The aim of this paper is to present a case study of a very low ozone event observed over the UK in January 2006. We first examine observations of this event and associated meteorological analyses. These suggest that the low observed ozone is due to the simultaneous occurrence of the two processes listed above. First, ozone in the mid-stratosphere is depleted. This probably occurs because the stratospheric vortex (and the ozone-poor air within it) has been transported from high latitudes to over the UK in the week or so leading up to 19 January. Second, on 18 and 19 January, an anticyclone is present in the troposphere and lower stratosphere over the UK. The associated lifting of the tropopause and lower stratospheric divergence will lead to a lowering of the ozone column.

In order to seek confirmation that such transport is actually taking place, we perform turbulent back trajectory calculations to determine the origin of the air arriving at Reading on 19 January, and the path that air took. These trajectories are calculated from the Met Office NAME III dispersion model (Ryall and Maryon, 1998; Jones et al., 2005). NAME III is a Lagrangian particle dispersion model which hitherto has primarily been used to investigate tropospheric pollution in a wide range of applications ranging from the dispersion of nuclear contamination and volcanic ash to the prediction of air quality levels based on thousands of UK and European anthropogenic and natural emissions. The results presented here show that the NAME III model can also be a very effective tool for diagnosing events in the stratosphere.

This paper brings together information from a number of sources in order to investigate this unusual low ozone event. Most of the observation and analysis data presented here are freely available in the public domain, except for the NAME III runs. This paper demonstrates how events of this kind can be quickly diagnosed without performing costly chemical transport model (CTM) runs. A full CTM representation of this event would offer complementary information, but this is beyond the scope of this paper.

The outline of the paper is as follows. In Sect. 2 the low ozone event is described via UK ground-based total ozone measurements, hemispheric maps of World Meteorological Organisation (WMO) Ozone Mapping Centre total ozone, and ozonesonde profiles from Lerwick, UK. The meteorological situation in the stratosphere and near the tropopause is described in Sect. 3 and is used to interpret the patterns shown in the ozone measurements. Then in Sect. 4 turbulent back trajectory calculations from the NAME III model are used to determine the origin of the air parcels that arrived at Reading on 19 January 2006. Conclusions appear in Sect. 5.

\section{Observations of the low ozone event}

We start by presenting observations made over the UK by Dobson spectrophotometers at Lerwick $\left(60.13^{\circ} \mathrm{N}, 1.18^{\circ} \mathrm{W}\right)$, Camborne $\left(50.13^{\circ} \mathrm{N}, 5.18^{\circ} \mathrm{W}\right)$ and Bracknell $\left(51.38^{\circ} \mathrm{N}\right.$, $\left.0.78^{\circ} \mathrm{W}\right)$ and by a Brewer spectrophotometer at Reading $\left(51.46^{\circ} \mathrm{N}, 0.97^{\circ} \mathrm{W}\right)$. The Lerwick observations used are from January 1979-present, the Reading observations from January 2003-present, and the Camborne and Bracknell observations are a combined dataset that spans November 1989 to December 2003.

The retrieval accuracy of the Dobson instrument is around $\pm 1 \%$ in direct sun conditions. In this paper we focus on January, when the sun is low, and the observational accuracy for this period is $\pm 4 \%$ (Komhyr, 1980). The retrieval accuracy of a well-maintained Brewer spectrophotometer is $\pm 1 \%$ and its precision is better than $\pm 1 \%$ (Gao et al., 2001).

At Reading, like in much of the northern hemisphere, minimum total ozone is observed between November and February. Figure 1 (top panel) shows 2005/06 observations for these months and the daily maximum and minimum values from the $2002 / 03$ to $2004 / 05$ winters. The minimum value recorded is 177 DU on 19 January 2006. This is more than 100 DU less than the minimum for 19 January for the previous observed winters and is also clearly less than the daily minimum for any other day in the November to February period (apart from the observation on 18 January 2006).

The dataset at Reading is too short to adequately represent interannual variability and therefore to gain an indication of this, we look at the daily maxima and minima from the 14 year long record from Camborne/Bracknell. These locations are sufficiently close to Reading for us to assume they approximately represent the 1989-2003 climatology for Reading. Figure 1 shows that the daily minimum for Camborne/Bracknell on 19 January is less than the 2002/032004/05 daily minimum at Reading, but it is still over 50 DU greater than the observation at Reading on 19 January 2006. 
The lower panel of Fig. 1 shows total ozone observations at Lerwick, which is approximately $10^{\circ}$ latitude north of Reading. It can be seen that the minimum total ozone for 2005/06 is observed on 18 January, one day before the minimum at Reading. Although this is a new low for the climatology envelope for this date, this minimum is less remarkable as it is fairly similar to other daily minima from the 1979-2005 record.

In order to gain a better idea of the spatial pattern of this total ozone event, we now look at daily maps of hemispheric total ozone. The maps are obtained from the WMO Ozone Mapping Centre (http://lap.physics.auth.gr/ozonemaps). The maps are created by assimilating total ozone data from the Scanning Imaging Absorption spectroMeter for Atmospheric CartograpHY (SCIAMACHY) using a transport model (Eskes et al., 2003). The transport model uses winds from European Centre for Medium Range Weather Forecasts (ECMWF) analyses. The SCIAMACHY total ozone columns are retrieved using the TOSOMI algorithm, which is described by Eskes et al. (2005). Validation shows a bias of around $-1.5 \%$ compared to Global Ozone Mapping Experiment (GOME) and ground-based observations.

Figure 2 shows daily WMO ozone maps from 15-20 January 2006. Focusing on latitudes north of $45^{\circ} \mathrm{N}$, we see that for all days the lowest ozone values ( $<350 \mathrm{DU})$ are most frequently seen over a large region spanning the North East Atlantic and Northern Europe. An examination of geopotential height at $46 \mathrm{hPa}$ and Ertel's potential vorticity at $520 \mathrm{~K}$ from Met Office analyses shows that the stratospheric vortex has been displaced from the pole and is located at approximately the same place as this low ozone region. This suggests that stratospheric ozone depletion contributes to the low ozone values. However, within the North East Atlantic/Northern Europe low ozone region defined above there is further structure, which is of synoptic scale. For example, on 17 January there are two regions of low ozone $(<300 \mathrm{DU})$ over the North East Atlantic and northern Scandinavia with higher ozone in between. This suggests a further process is also acting to reduce total ozone. The synoptic pattern is indicative of a change in column ozone related to the passage of tropospheric weather systems.

To get a better idea of what is happening to the vertical distribution of ozone, we now move away from total column observations to look at ozone profiles measured by a Met Office ozonesonde at Lerwick. The sonde is of the Electrochemical Concentration Cell (ECC) type. The total error for ECC sondes is estimated to be within $-7 \%$ to $+17 \%$ in the upper troposphere, $\pm 5 \%$ in the lower stratosphere up to $10 \mathrm{hPa}$ and $-14 \%$ to $+6 \%$ at $4 \mathrm{hPa}$ (Komhyr et al., 1995). Errors are higher in the presence of steep ozone gradients and where ozone amounts are low.

During winter, the sonde usually makes one ascent per week. Figure 3 shows that on 18 January 2006 ozone mixing ratios between 50 and $10 \mathrm{hPa}$ are around 3-3.5 ppmv. This is up to 2 ppmv less than corresponding values from observa-
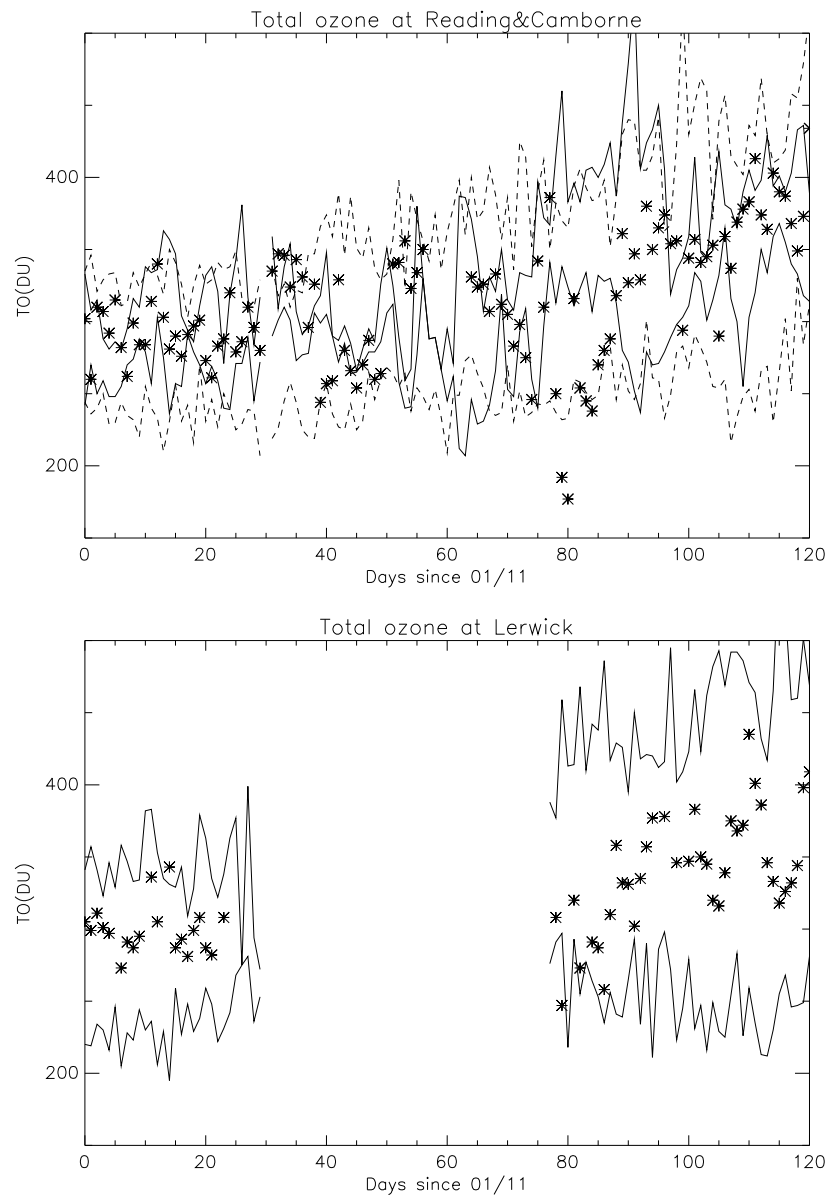

Fig. 1. Total ozone observations between 1 November and 29 February. Top panel: observations at Reading between 1 November 2005 and 28 February 2006 (asterisks), daily maximum and minimum total ozone at Reading from January 2003-February 2005 data (solid lines), daily maximum and minimum total ozone at Camborne/Bracknell from 1989-2003 data (dashed lines). Bottom panel: observations at Lerwick between 1 November 2005 and 28 February 2006 (asterisks), daily maximum and minimum total ozone at Lerwick from January 1979-February 2005 data (solid lines).

tions made on 4 and 11 January 2006 and also around 1 ppmv lower than the January climatology of Lerwick radiosonde ascents. Further evidence of stratospheric ozone loss on similar dates are also shown in Fig. 3 from ozonesonde profiles from Sodankylä, Finland $\left(67.35^{\circ} \mathrm{N}, 26.63^{\circ} \mathrm{E}\right)$. Between around 50 and $10 \mathrm{hPa}$ the ozone profiles on 5 and 18 January at Sodankylä are broadly similar to those on 4 and 18 January, respectively, at Lerwick. At lower altitudes, at around $200-80 \mathrm{hPa}$, the ozone values at Lerwick are up to $1 \mathrm{ppmv}$ lower than climatology for both 4 and 18 January.

It is thus evident from Fig. 3 that there are two distinct areas, the UTLS and the mid-stratosphere, with low ozone values over Lerwick on 18 January 2006. An analysis of the 


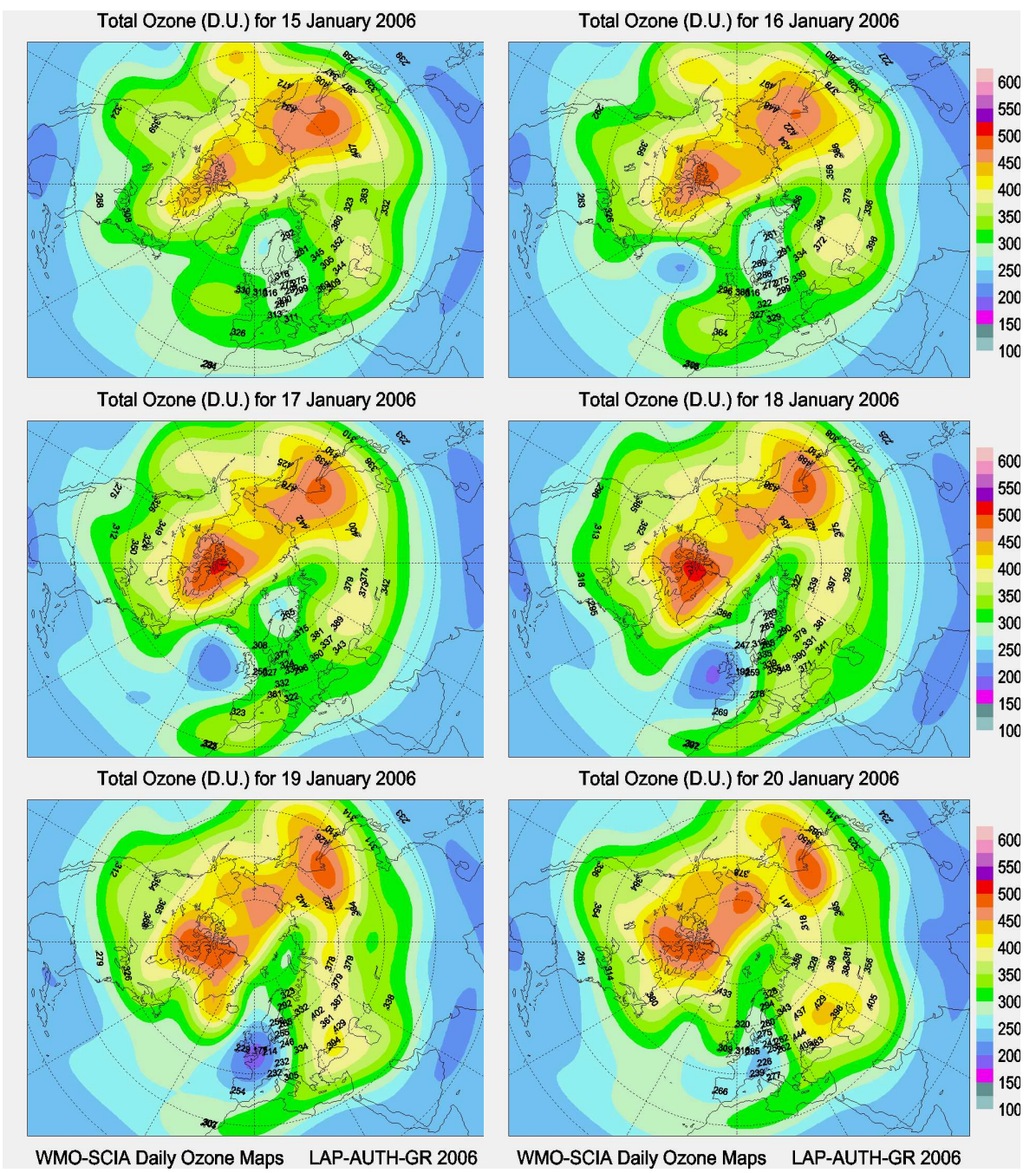

Fig. 2. Total ozone maps from the WMO Ozone Mapping Centre for 15-20 January 2006.
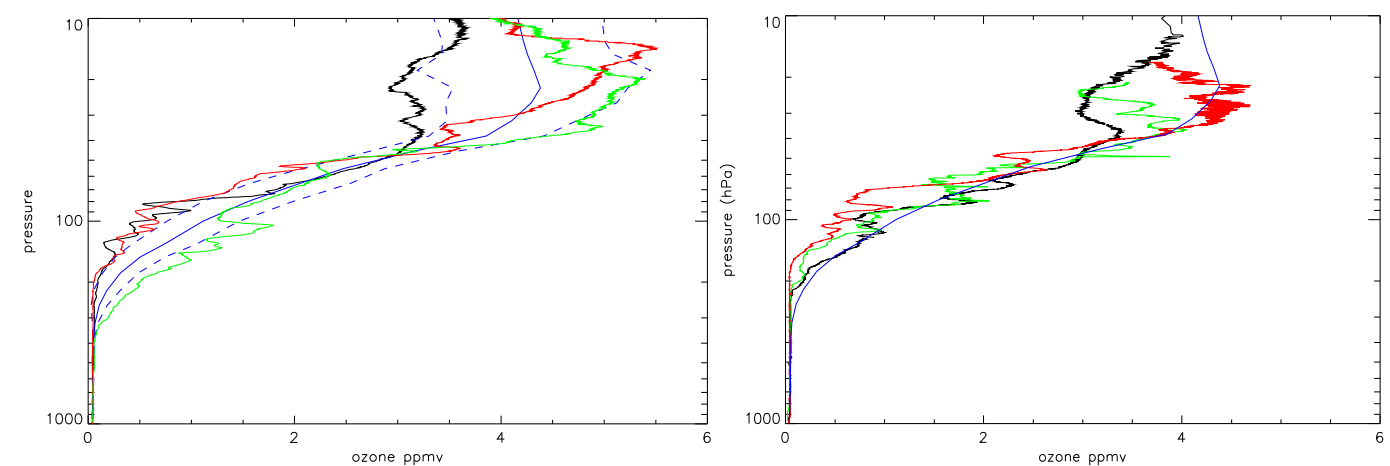

Fig. 3. Ozone profiles measured by ozonesondes at Lerwick on the left hand plot and Sodankylä, Finland, on the right hand plot. The red line corresponds to 4 and 5 January 2006 for Lerwick and Sodankylä, respectively, the green line 11 January 2006, the black line 18 January 2006. The January climatology of Lerwick radiosonde ascents is shown in blue on both plots (dashed represents $\pm 1 \sigma$ ). Units: ppmv. 

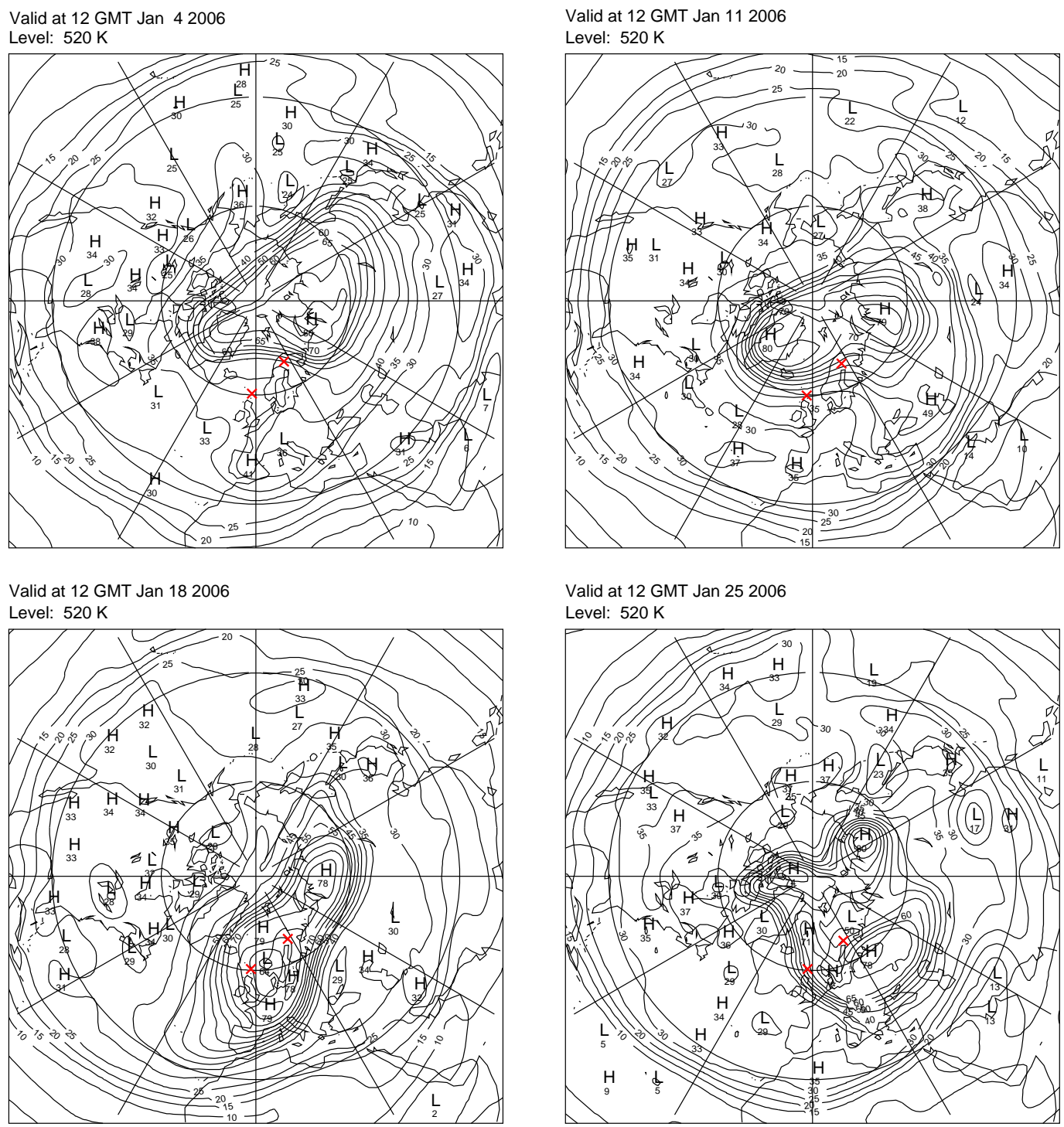

Fig. 4. PV on the $520 \mathrm{~K}$ theta surface (approx. $50 \mathrm{hPa}$ ) derived from Met Office analyses on 4 January 2006 (top left), 11 January 2006 (top right), 18 January 2006 (bottom left), 25 January 2006 (bottom right). Contour interval 5 PV units. Crosses mark the locations of Lerwick and Sodankylä.

Lerwick ozone profile data was performed in order to assign values to the amount of depletion from these two vertical regions. The profiles were split into two at $65 \mathrm{hPa}$ and the separate areas were compared with the January climatology. The depletion attributed to each of these layers (surface to $65 \mathrm{hPa}$ and $65 \mathrm{hPa}$ to $10 \mathrm{hPa}$ ) was calculated in terms of total column ozone. The results reveal that approximately a third (34\%) of the depletion in the total ozone column (w.r.t the January climatology) originates from the mid-stratospheric $65-10 \mathrm{hPa}$ region, while two thirds $(66 \%)$ comes from the UTLS region (note that the climatology and daily profiles are very similar for the majority of the troposphere). This analysis confirms that important ozone depleting processes occur in two distinct regions and they are discussed further in Sect. 3.

\section{Meteorological situation}

In this section we use daily Met Office stratospheric analyses (Swinbank et al., 2004) to describe the meteorological situation in January 2006. Unlike the cold, undisturbed Northern Hemisphere winter of 2004/5, the stratosphere has been dynamically disturbed in 2005/6. In mid January there was a minor stratospheric warming, which became a major warming on 21 January and persisted until early February. A major stratospheric warming occurs when the temperature gradient at $10 \mathrm{hPa}$ (around $30 \mathrm{~km}$ ) between $60^{\circ} \mathrm{N}$ and the pole is reversed to become warmer towards the pole. In addition the zonal mean polar night jet reverses from westerly to easterly at $60^{\circ} \mathrm{N}$ and $10 \mathrm{hPa}$. The intensity and duration of the 

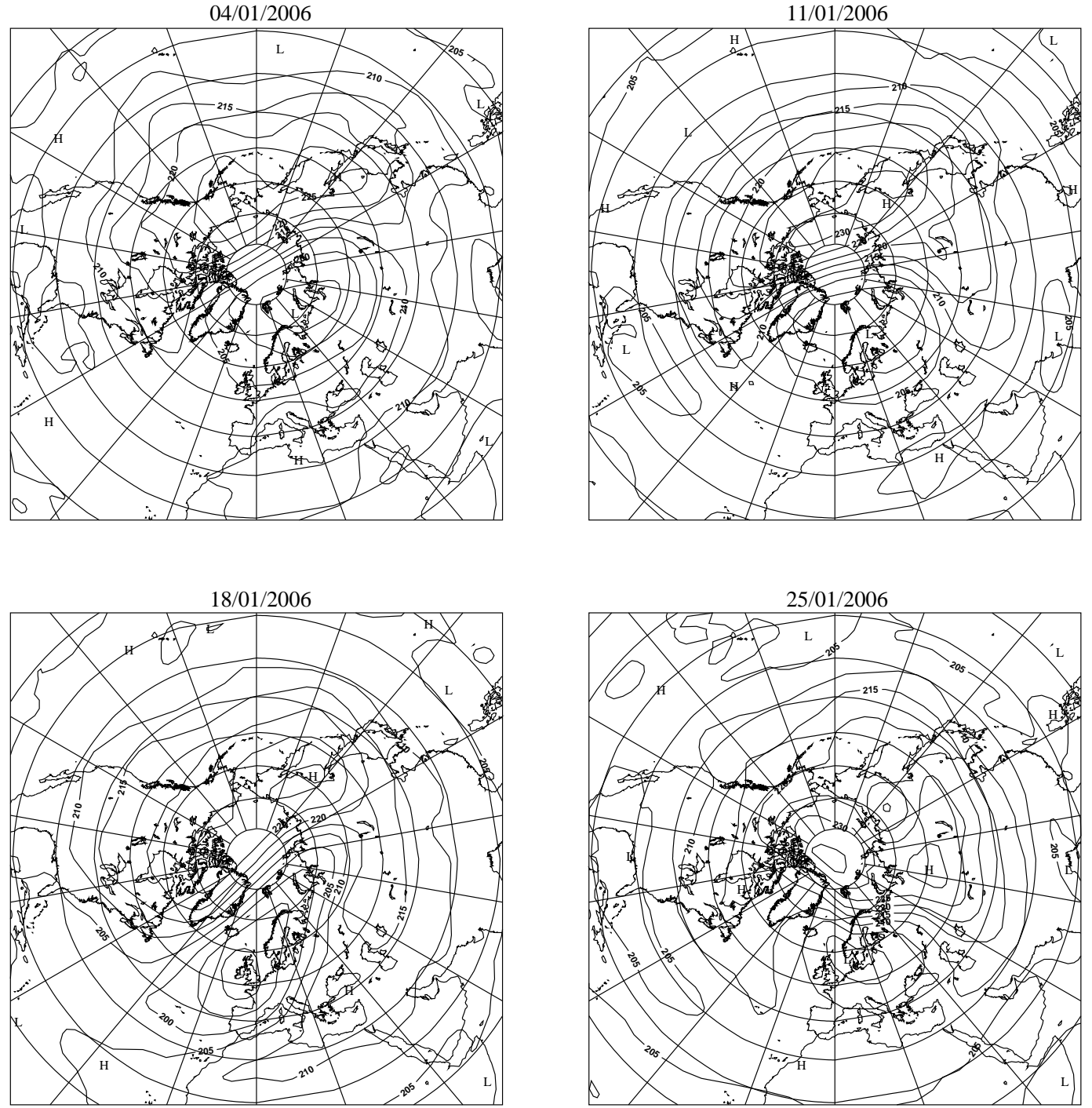

Fig. 5. Temperature at $46 \mathrm{hPa}$ from Met Office analysis on 4 January 2006 (top left), 11 January 2006 (top right), 18 January 2006 (bottom left), 25 January 2006 (bottom right). Contour interval $5 \mathrm{~K}$.

January 2006 major warming are greater than average.

The typical meteorological situation for a cold, undisturbed, January (such as in 2005) is a near-zonally symmetric polar vortex, centred near the pole and with associated cold temperatures. The analyses from January 2006 show a very different picture. Figure 4 shows Ertel's potential vorticity on the $520 \mathrm{~K}$ isentropic surface (approximately $50 \mathrm{hPa}$ ) for selected days in January 2006. The impact of the January 2006 warming is a significant displacement of the polar night vortex away from the pole. During the course of the month the vortex becomes increasingly distorted and moves southwards and eastwards across the North Atlantic and Northern Europe.

The southward movement of the vortex also implies southward movement of the cold air within it. This is reflected in
Fig. 5 which is similar to Fig. 4, except that temperatures at $46 \mathrm{hPa}$ are shown. By 18 January minimum temperatures of less than $195 \mathrm{~K}$ are located over the British Isles. From then until 25 January this cold air is transported eastward across the British Isles and into central Europe. The Met Office analyses show that the temperature in the polar vortex had fallen below the critical threshold for type I PSC formation $(195 \mathrm{~K}$ at $46 \mathrm{hPa})$ in 22 of the 31 days prior to the observed event on 19 January. PSCs at similar locations are also seen in SCIAMACHY observations (von Savigny et al., 2005) on these days (data available from: http://www-iup. physik.uni-bremen.de/ sciaproc/PSC/PSC_2006_S00.html).

The low temperatures and the presence of PSCs during December and January indicate that the air within the polar vortex is likely to be ozone poor for at least a week prior to 18 

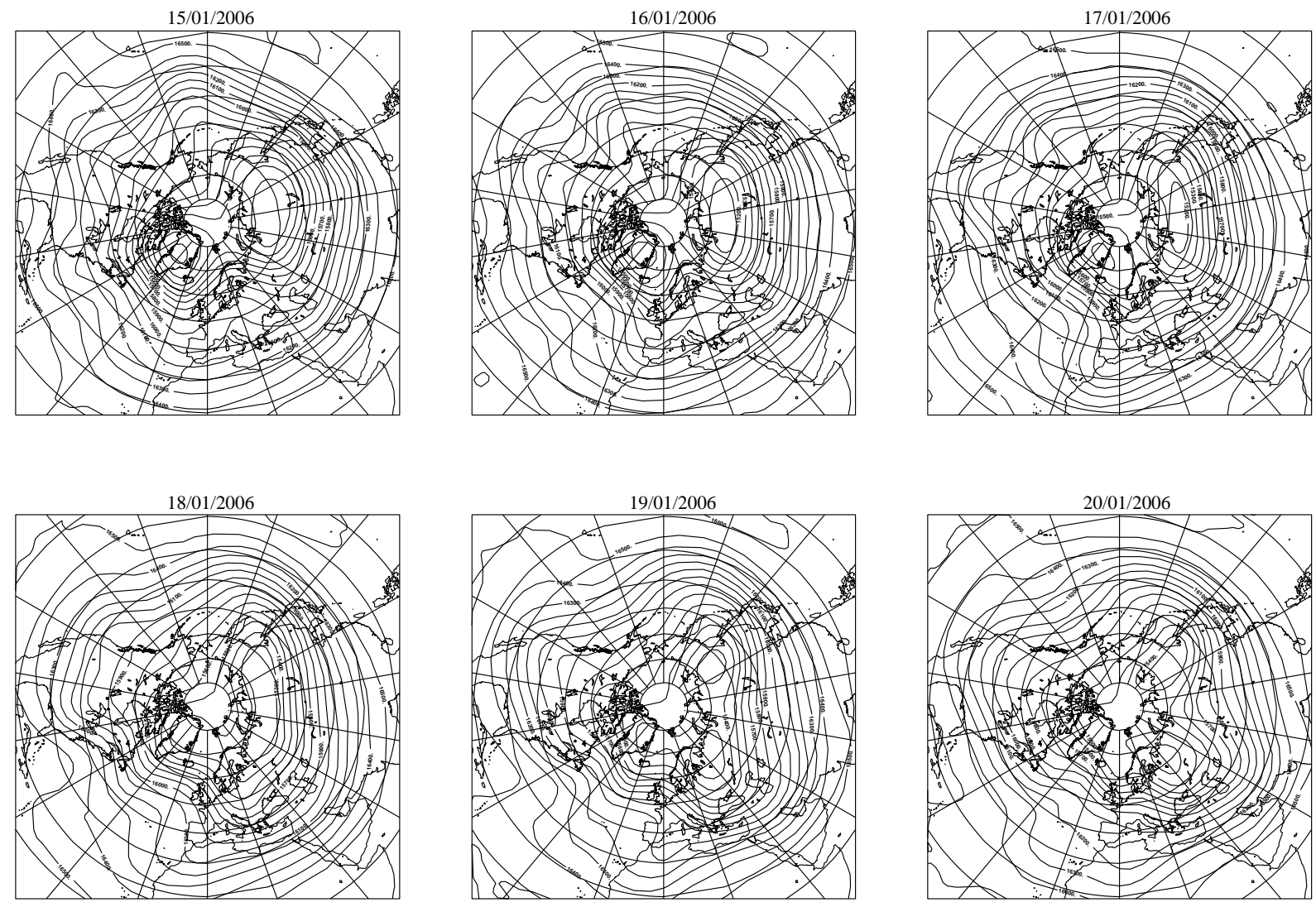

Fig. 6. Geopotential height at $100 \mathrm{hPa}$ from Met Office analyses on 15 January 2006 (top left), 16 January 2006 (top centre), 17 January 2006 (top right), 18 January 2006 (bottom left), 19 January 2006 (bottom centre) and 20 January 2006 (bottom right). Contour interval: 10 dam.

January. This is confirmed by a comparison of Figs. 3 and 4 . Figure 4 suggests that both Lerwick and Sodankylä are inside the polar vortex on 18 January and outside it on 4 January (on 11 January, Lerwick is outside the vortex and Sodankylä is on the edge of the vortex). Figure 3 shows that mid stratosphere ozone at these sites is less when the observations are made inside the vortex than outside the vortex. Thus, the low ozone air observed at Lerwick on 18 January is very likely a result of Lerwick being inside the polar vortex on that date. Maps of Ertel's potential vorticity also show that Reading is within the stratospheric polar vortex on 19 January (not shown) and so it appears that the presence of ozone poor stratosphere vortex air also contributes to the record low ozone column observed at Reading on that date.

Some of the ozone depletion at Lerwick on 18 January is probably due to local heterogeneous chemical destruction associated with the presence of the PSCs implied by Fig. 5, rather than by the transport of pre-existing ozone-poor air to Lerwick. A quantification of the relative contributions of both these processes requires detailed chemical modelling studies, which are outside the scope of this study.

As indicated in Sects. 1 and 2, another mechanism for a reduction in total ozone column is the raising of the tropopause associated with the passage of anticyclones. Figure 6 shows geopotential height at $100 \mathrm{hPa}$ from Met Office analyses for 15-20 January 2006. Focusing on the middle latitudes between the central North Atlantic and Russia, we see that there is a clear link between anticyclones (cyclones), which can be seen as ridges (troughs) in Fig. 6, and depletions (enhancements) in the SCIAMACHY total ozone columns (Fig. 2). In addition, these features can also be associated with the surface pressure fields (not shown). In particular, the strong ridging pattern in the $100 \mathrm{hPa}$ geopotential height fields can be related to large surface high pressure systems.

The origin of the ozone minimum over the British Isles on 19 January is seen on 16 January. On that date there are ozone minima (see Fig. 2) over the central North Atlantic and Scandinavia which are associated with anticyclones (Fig. 6) in these regions. The Atlantic anticyclone moves eastward over the next few days, reaching the British Isles on 19 January, and the associated eastward movement of the ozone minimum can be seen in Fig. 2. By 20 January a low pressure system appears to the north of the British Isles, with an associated rise in ozone column (seen as a trough in Fig. 6). In subsequent days there is a continued fall/rise in total ozone over the British Isles associated with the passage of 
anticyclones/cyclones, but the very low ozone column seen on 18 and 19 January is not observed again.

The passage of anticyclones and the associated raising of the tropopause leads to net divergence in the stratospheric air aloft, thus removing relatively ozone rich air from the column. A simple analysis of the stratospheric air above Reading on 18 January confirms that net divergence takes place in the $100-10 \mathrm{hPa}$ column.

Similar synoptic situations to those described are seen in the Met Office $100 \mathrm{hPa}$ geopotential height fields in early January 2006. However, it is interesting that the SCIAMACHY fields do not show such a deep minimum in total ozone on these dates. This is confirmed by the ground-based observations in Fig. 1. This suggests that the very low ozone columns on 18 and 19 January are due to a combination of the presence of a UTLS anticyclone and of ozone depletion aloft.

\section{NAME III model simulations}

In this section we use the Met Office's dispersion model, NAME III, to obtain further confirmation of the transport processes responsible for the low ozone event over the UK. NAME III is a Lagrangian particle dispersion model (Ryall and Maryon, 1998; Jones et al., 2005) within which emissions from pollutant sources are represented by particles released into a model atmosphere. The particles are then advected by the mean winds as calculated by the Met Office's numerical weather prediction model, the Unified Model (Davies et al., 2005). Turbulent diffusion of the particles is modelled through the application of various random walk techniques (Rodean, 1996). Parameterizations also represent processes such as the entrainment between the boundary layer and the free troposphere, the mixing by deep convection, both wet and dry deposition, sedimentation and chemical destruction and creation. The model is routinely used in a wide range of applications: examples include the prediction of air quality levels based on thousands of UK and European anthropogenic and natural emissions, the transport and deposition of debris following the Chernobyl accident (Smith and Clark, 1989) and the airborne spread of foot and mouth disease during the epidemic in the UK in 2001 (Gloster et al., 2001).

In addition, a key advantage of utilizing a Lagrangian approach for dispersion modelling is the ability to run the model backwards in time. In this configuration particles are 'released' from the receptor location and the resulting plots show where the air came from to arrive at the receptor. This enables sources to be identified from receptor data (Manning et al., 2003). Here, NAME III employs full turbulent transport and dispersion, referred to here as turbulent trajectories for simplicity. This requires that thousands of model particles be released which results in the identification of source areas rather than points, as is the case with the more simple back trajectory approach. This capability makes it possible to identify the origin or origins (both time and location) of the air reaching a location at any given time.

Simulations with the NAME III model were run to investigate the origins of the air contributing to the low ozone event over Reading on 19 January. Accordingly, a receptor was defined corresponding to the centre of the observed low ozone region, at $51.46^{\circ} \mathrm{N} 0.97^{\circ} \mathrm{W}$, on that date. Simulations were run backwards in time for 5 days from this date, providing maps of the origin/path of the air arriving at this location. NAME III was driven by the analysis fields from the Met Office operational global weather prediction model, with the top of the domain being restricted to $30 \mathrm{~km}$.

In order to assist in understanding the results a series of simulations were carried out using a receptor measuring $100 \mathrm{~km}^{2}$ in the horizontal and extending from $10 \mathrm{~km}$ to $30 \mathrm{~km}$ in altitude. The receptor was then repositioned at 5 different horizontal locations (North, South, East, West and Central) covering the extent of the observed low ozone feature. Results for all the different horizontal locations are very consistent. This indicates that, over an area of $10^{\circ}$ in latitude and longitude centred at $51.46^{\circ} \mathrm{N} 0.97^{\circ} \mathrm{W}$ (the low ozone area), the simulations are spatially robust. Accordingly, all plots included here are for the central location.

NAME III results are presented in Figs. 7 to 10. These figures show where air arriving at the receptor on 19 January 2006 between 11:00:00 and 13:00:00 UTC originated from and passed through during a five day period preceding this time. The contours represent the time integrated air concentration from each model output grid box $(\mathrm{dx}, \mathrm{dy}, \mathrm{dz})$ that contributes to the receptor. Each of the figures shows only the air that originated/passed through a certain depth of the atmosphere to arrive at the receptor. In all cases the receptor's size and location is the same.

Figure 7 shows the air origin map for air originating over the whole vertical extent of the model i.e., $0-30 \mathrm{~km}$. Much of the air mass arriving at the receptor originates in an area between Iceland and North West Russia. Comparisons with Met Office stratospheric Ertel's potential vorticity maps for January (Fig. 4) suggest that this flow is very similar to the flow of the stratospheric polar vortex. In order to better determine the origins of the air, further plots are shown which only show air arriving at the receptor that has originated/passed through certain atmospheric layers. Figure 8 is similar to Fig. 7, except that it only shows air arriving at the receptor that has originated/passed through a layer extending from $15-30 \mathrm{~km}$. This confirms that the air originating between Iceland and North West Russia is stratospheric in origin.

Figure 7 also shows air originating from other locations, such as the Pacific and the northern subtropical Atlantic. Figure 8 shows that little or none of this air originates from the $15-30 \mathrm{~km}$ layer, so in order to determine the origin of this air, further vertical slices at $10-15 \mathrm{~km}$ and $5-10 \mathrm{~km}$ were examined, and these are shown in Figs. 9 and 10, respectively. Both plots show that a proportion of the air arriving at the 


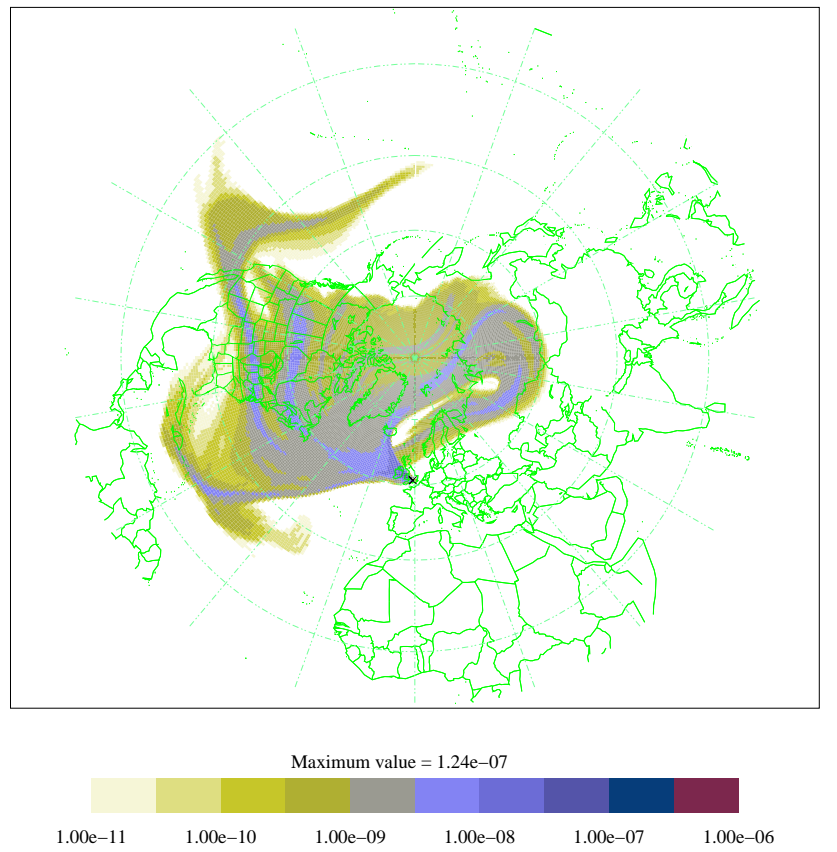

Fig. 7. NAME III derived five day air history map for parcels originating in or passing through the $0-30 \mathrm{~km}$ vertical region from a receptor of $100 \mathrm{~km}^{2}$ horizontal area with a $10-30 \mathrm{~km}$ vertical extent centred on $51.46^{\circ} \mathrm{N}, 0.97^{\circ} \mathrm{W}$ (black cross). The contours represent the time integrated air concentration from each grid box (dx,dy,dz) that contributes to the receptor on 19 January 2006 between 11:00 and 13:00 UTC given a release rate of $1 \mathrm{~g} / \mathrm{s}$.

receptor has travelled from the equatorial western Atlantic with a considerable northward component. It should be remembered that for air to appear in any of the plots it must arrive at the receptor location at an altitude of $10-30 \mathrm{~km}$. Therefore, Fig. 10 also indicates that some of the air arriving at the receptor has ascended from the $5-10 \mathrm{~km}$ layer.

Figure 9 indicates that most of the air originating from the $10-15 \mathrm{~km}$ layer that subsequently arrives at the receptor location is not polar vortex in origin. The flow is very similar in pattern to the geopotential height fields at $100 \mathrm{hPa}$ in Fig. 6 and, close to the receptor, the trajectories follow an anti-cyclonic path. Figure 10 shows that there is also a volume of air originating in the northern subtropical Atlantic from an altitude between $5 \mathrm{~km}$ and $10 \mathrm{~km}$ that took $3-5$ days to arrive at the receptor location. This air also follows an anti-cyclonic path close to the receptor region.

We can see from Figs. 7-10 that air arriving at the receptor region has two main sources. Air originating from the 15$30 \mathrm{~km}$ region is primarily stratospheric vortex in origin, with very little transport from elsewhere. In the previous section we showed that this air is likely to be ozone poor prior to arriving over the British Isles on 18 and 19 January.

The air arriving at the receptor from the $5-10 \mathrm{~km}$ and 10 $15 \mathrm{~km}$ layers is likely to have undergone horizontal and ver-

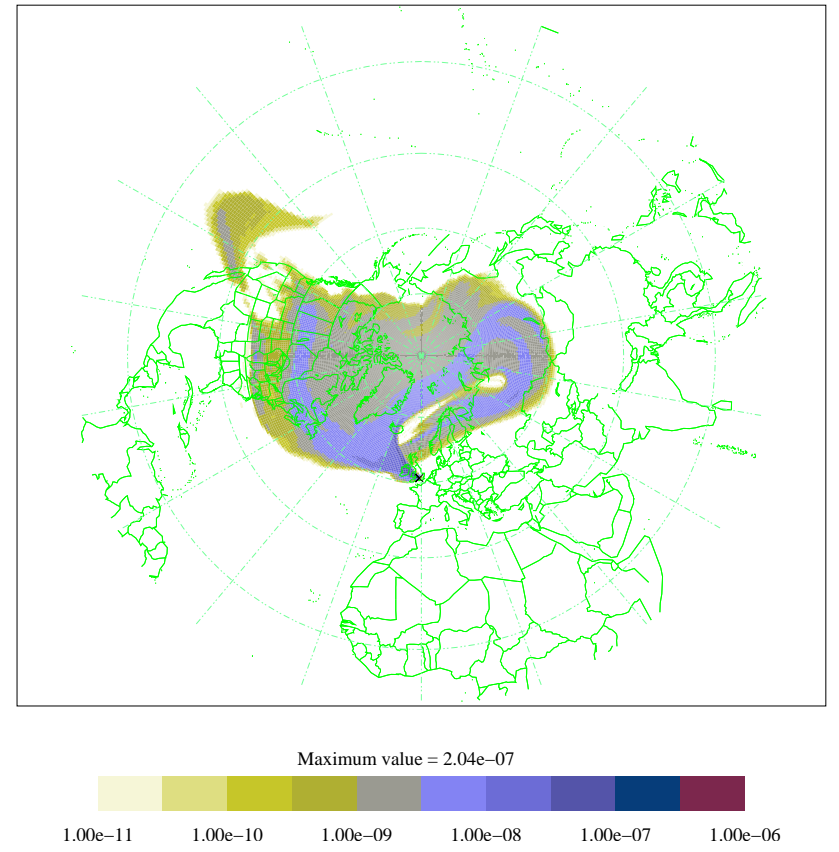

Fig. 8. As previous figure, except results are shown for air originating from or passing through the $15-30 \mathrm{~km}$ vertical region.

tical transport related to the passage of cyclones and anticyclones shown in Fig. 6. Close to the receptor, the flow regime is anticyclonic which is consistent with a raised tropopause and divergence in the lower stratosphere. Accordingly, this leads to a decrease in the total ozone column. The results also show transport from low latitudes and low levels (see Fig. 10). However, the NAME III results by themselves cannot tell us whether this will lead to a further decrease, or an increase, in the ozone column at the receptor. These results were in agreement with other NAME III runs based on receptor regions for the low ozone area on 17 and 18 January, which showed air transported to the receptor region from similar areas.

\section{Conclusions}

A record low total column ozone value of $177 \mathrm{DU}$ was observed at Reading, UK on 19 January 2006. In addition, ozonesonde observations from Lerwick show a large depletion in mid-stratospheric ozone between 50 and $10 \mathrm{hPa}$ around this date, together with a noticeable decrease in the ozone around the UTLS, $200-80 \mathrm{hPa}$, region. Analysis of the ozonesonde data indicates that around one third of the depletion in the total ozone column originates from the middle stratosphere, and the rest is caused by the reduction in UTLS ozone values. This indicates that important ozone depleting processes were at work in two different regions.

Met Office analyses show that at this time the stratospheric polar vortex was displaced over the British Isles. Evidence 

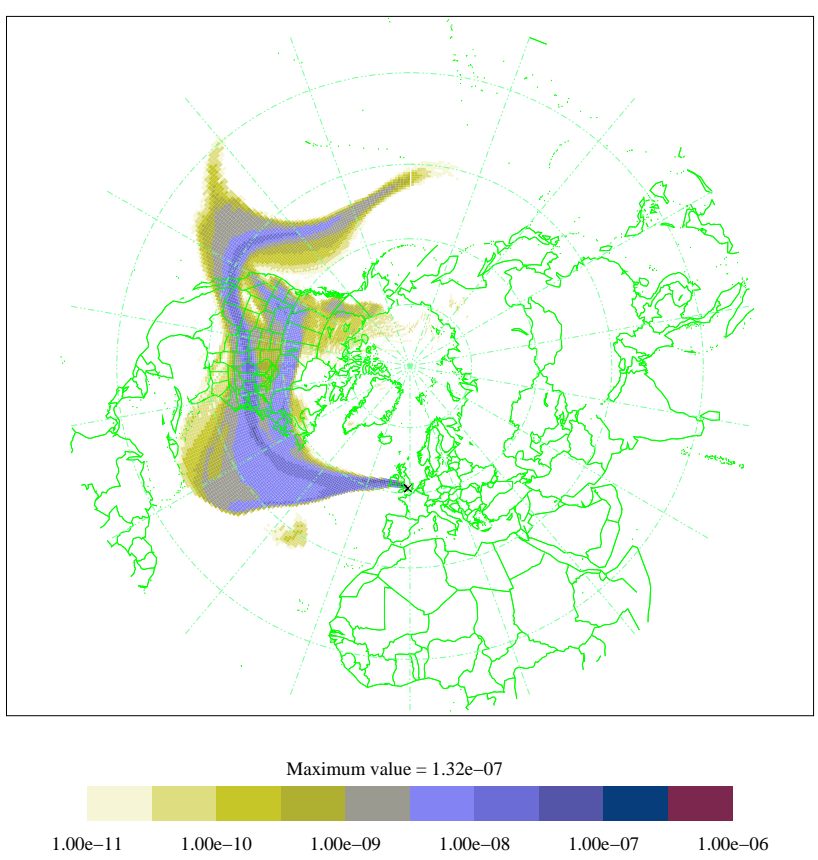

Fig. 9. As Fig. 8, except results are shown for air originating from or passing through the $10-15 \mathrm{~km}$ vertical region.
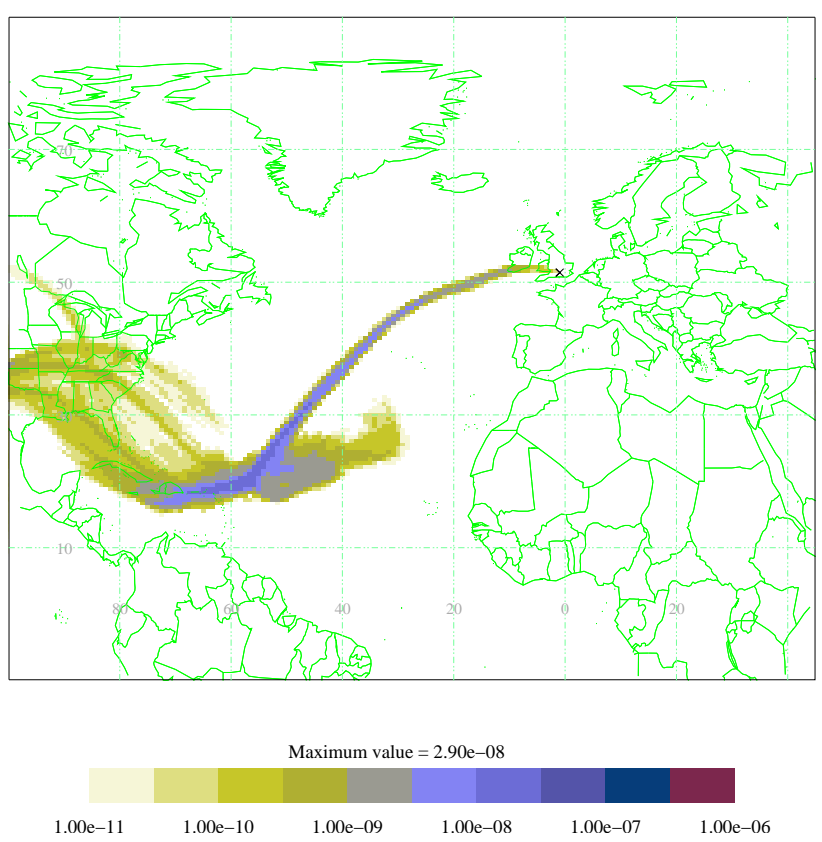

Fig. 10. As Fig. 8, except results are shown for air originating from or passing through the $5-10 \mathrm{~km}$ vertical region.

from Lerwick and Sodankylä ozonesondes, and Met Office fields of Ertel's potential vorticity, suggests that the British Isles was beneath the stratospheric vortex at this time and that the air within the vortex was already ozone poor. This low ozone air contributes to the record low ozone column ob- served at Reading. The temperatures within the vortex were low enough to cause PSC formation and thus local ozone destruction via heterogeneous chemistry, and it is a possibility that this could further add to the ozone depletion. However, without using a chemical model it is impossible to quantify how much ozone depletion could come from this source.

WMO total ozone maps show a large region of low ozone over the North East Atlantic and Northern Europe which is approximately colocated with the displaced polar vortex. However, superimposed on this low ozone region is a smaller, synoptic, scale pattern of middle latitude ozone column depletion. This points to another cause for the low ozone over the British Isles, namely the impact of anticyclones in reducing the total ozone column. These events are well documented, see e.g. Newman et al. (1988); McKenna et al. (1989); Peters et al. (1995); James (1998), and frequently observed. They occur because associated with the presence of the anticyclone is a raising of the tropopause, meaning that a greater proportion of the column is occupied by ozone-poor tropospheric air. In addition, the divergence of ozone-rich air out of the column in the lower stratosphere leads to a further reduction in total ozone. We have shown that there is a strong link between the patterns of total ozone minima seen in the WMO maps and the location of anticyclones in $100 \mathrm{hPa}$ geopotential height fields from Met Office analyses. Therefore, it appears that this mechanism also contributes to the record low ozone columns observed.

In order to confirm the existence of these mechanisms we perform back trajectory calculations using the NAME III model. The receptor point for the trajectories was Reading. The results show that middle stratosphere air has been transported in the polar vortex from higher latitudes from the region of lowest temperatures, and this adds further weight to the hypothesis that this air will have undergone ozone destruction due to heterogeneous chemistry prior to reaching the region of observed low ozone in mid latitudes. The model results also show that air transported from near-tropopause levels $(5-15 \mathrm{~km})$ arrives at the receptor point in an anticyclonic path. This pattern is consistent with what is shown in Met Office analyses of geopotential height at $100 \mathrm{hPa}$ and WMO total ozone maps, and also with previous trajectorybased studies of ozone miniholes over Europe, e.g. Koch et al. (2002). It clearly confirms that the synoptic scale reductions in ozone seen in these maps is associated with the raising of the tropopause and lower stratospheric divergence that occurs in the presence of these anticyclones.

It is important to note the possible health impacts of such decreased ozone events. Austin et al. (1999) reported record low ozone in late April/early May 1997 over southern England. The erythemally-weighted ultraviolet levels recorded at this time were similar to those normally recorded in June or July, and the impacts on human health of exposure to this abnormally high amount of radiation are clear. Similarly, Stick et al. (2006) reported unusually large UV values over northern Germany in May 2005 as a result of an ozone mini-hole. 
The event in January 2006 that we have reported may have some impact on the biosphere, but is unlikely to have many consequences for human health since erythemally-weighted ultraviolet levels do not usually start to become significant at middle or high latitudes until around a month after the spring equinox.

Acknowledgements. The authors would like to thank H. Eskes from KNMI for the provision of assimilated ozone fields to the WMO ozone mapping centre. D. Moore provided Met Office ozonesonde data and his knowledge of the observations was extremely helpful. Sodankylä ozonesonde data were obtained from the NILU database. Netcen provided the UK surface observations from Reading and Lerwick on behalf of DEFRA. Comments from the referees and a number of Met Office colleagues resulted in considerable improvements to this study.

Edited by: H. Wernli

\section{References}

Allen, D. R. and Nakamura, N.: Dynamical reconstruction of the record low column ozone over Europe on 30 November 1999, Geophys. Res. Lett., 29, 1362, doi:10.1029/2002GL014935, 2002.

Austin, J., Driscoll, C. M. H., Farmer, S. F. G., and Molyneux, M. J.: Late spring ultraviolet levels over the United Kingdom and the link to ozone, Ann. Geophys., 17, 1199-1209, 1999,

http://www.ann-geophys.net/17/1199/1999/.

Davies, T., Cullen, M. J. P., Malcolm, A. J., Mawson, M. H., Staniforth, A., White, A. A., and Wood, N.: A new dynamical core for the Met Office's global and regional modelling of the atmosphere, Q. J. R. Meteorol. Soc., 131, 1759-1782, 2005.

Eskes, H. J., van Velthoven, P. F. J., Valks, P. J. M., and Kelder, H. E.: Assimilation of GOME total ozone satellite observations in a three-dimensional tracer transport model, Q. J. R. Meteorol. Soc., 129, 1663-1681, 2003

Eskes, H. J., van der A, R. J., Brinksma, E. J., Veefkind, J. P., de Haan, J. F., and Valks, P. J. M.: Retrieval and validation of ozone columns derived from measurements of SCIAMACHY on Envisat, Atmos. Chem. Phys. Discuss., 5, 4429-4475, 2005, http://www.atmos-chem-phys-discuss.net/5/4429/2005/.

Gao, W., Slusser, J., Gibson, J., Scott, G., Bigelow, D., Kerr, J., and McArthur, B.: Direct-Sun column ozone retrieval by the ultraviolet multifilter rotating shadow-band radiometer and comparison with those from Brewer and Dobson spectrophotometers, Appl. Opt., 40, 3149-3155, 2001.

Gloster J., Champion H. J., Mansley L. M., Romero P., Brough, T., and Ramirez A.: The 2001 epidemic of foot-and-mouth disease in the United Kingdom: epidemiological and meteorological case studies, The Veterinary Record, 156, 793-803, 2001.

Hood, L. L. and Soukharev, B. E.: Interannual variations of total ozone at Northern midlatitudes correlated with stratospheric EP flux and potential vorticity, J. Atmos. Sci., 62, 3724-3740, 2005

James, P. M.: A climatology of ozone mini-holes over the northern hemisphere, Int. J. Climatology, 18, 1287-1303, 1998.
James, P. M. and Peters, D.: The Lagrangian structure of ozone mini-holes and potential vorticity anomalies in the Northern Hemisphere, Ann. Geophys., 20, 835-846

Jones, A., Thomson, D., Hort, M., and Devenish, B.: The U. K. Met Office's next generation atmospheric dispersion model NAME III, Air pollution modeling and its application XVII, edited by: Borrego, C. and Norman, A., 580-589, Springer, 2007.

Koch, G., Wernli, H., Staehelin, J., and Peter, T.: A Lagrangian analysis of stratospheric ozone variability and long-term trends above Payerne (Switzerland) during 1970-2001, J. Geophys. Res., 107, 4373, doi:10.1029/2001JD001550, 2002.

Koch, G., Wernli, H., Schwierz, C., Staehelin, J., and Peter, T.: A composite study on the structure and formation of ozone miniholes and minihighs over central Europe, Geophys. Res. Lett., 32, L12810, doi:10.1029/2004GL022062, 2005.

Komhyr, W. D.: Ozone Observations with a Dobson Spectrophotometer, WMO Global Ozone Research and Monitoring Project Report No. 6, NOAA Environmental Research Laboratories, 1980.

Komhyr, W. D., Barnes, R. A., Brothers, G. B., Lathrop, J. A., and Opperman, D. P.: Electrochemical Concentration Cell ozonesonde performance evaluation during STOIC 1989, J. Geophys. Res., 100, 9231-9244, 1995.

Manning, A. J., Ryall, D. B., Derwent, R. G., Simmonds, P. G., and O'Doherty, S.: Estimating European emissions of ozonedepleting and greenhouse gases using observations and a modelling back-attribution technique, J. Geophys. Res., 108, 4405, doi:10.029/2002JD002312, 2003.

McKenna, D. S., Jones, R. L., Austin, J., Browell, E. V., McCormick, M. P., Krueger, A. J., and Tuck, A. F.: Diagnostic studies of the Antarctic vortex during the 1987 Airborne Antarctic Ozone Experiment - ozone miniholes, J. Geophys. Res., 94, 11 641-11 668, 1989.

Newman, P. A., Lait, L. A., and Schoeberl, M. R.: The morphology and meteorology of southern-hemisphere spring total ozone mini-holes, Geophys. Res. Lett., 15, 923-926, 1988.

Peters, D., Egger, J., and Entzian, G.: Dynamical aspects of ozone mini-hole formation, Meteorol. Atmos. Phys., 55, 205214, 1995.

Peters, D. and Entzian, G.: Longitude-dependent decadal changes of total ozone in boreal months during 1979-1992, J. Climate, $12,1038-1048$

Petzoldt, K., Naujokat, B., and Neugeboren, K.: Correlation between stratospheric temperature, total ozone, and tropospheric weather systems, Geophys. Res. Lett., 21, 1203-1206, 1994.

Petzoldt, K.: The role of dynamics in total ozone deviations from their long-term mean over the Northern Hemisphere, Ann. Geophys., 17, 231-241, 1999, http://www.ann-geophys.net/17/231/1999/.

Rodean, C.: Stochastic Lagrangian models of turbulent diffusion, Am. Met. Soc. Meteorological Monographs, 26(48), 1996.

Ryall, D. B. and Maryon, R. H.: Validation of the UK Met. Office's NAME model against the ETEX dataset (1998), Atmospheric Environment, 32, 4265-4276, 1998.

Stick, C., Krüger, K., Schade, N. H., Sandmann, H., and Macke, A.: Episode of unusually high solar ultraviolet radiation over central Europe due to dynamical reduced total ozone in May 2005, Atmos. Chem. Phys., 6, 1771-1776, 2006, http://www.atmos-chem-phys.net/6/1771/2006/. 
Smith, F. B. and Clark, M. J.: The transport and deposition of airborne debris from the Chernobyl nuclear power plant accident with special emphasis on the consequences to the United Kingdom, Meteorological Office Scientific Paper No. 42, HMSO (available from Met Office, FitzRoy Road, Exeter EX1 3PB, UK), 1989.

Swinbank, R., Keil, M., Jackson, D. R., and Scaife, A. A.: Stratospheric Data Assimilation at the Met Office - progress and plans. ECMWF workshop on Modelling and Assimilation for the Stratosphere and Tropopause, 23-26 June 2003, 2004 von Savigny, C., Ulasi, E. P., Eichmann, K. U., Bovensmann, H., and Burrows, J. P.: Detection and mapping of polar stratospheric clouds using limb scattering observations, Atmos. Chem. Phys., 5, 3071-3079, 2005,

http://www.atmos-chem-phys.net/5/3071/2005/. 